\title{
PRAMOEDYA ANANTA TOER AND CHINA: THE TRANSFORMATION OF A CULTURAL INTELLECTUAL.
}

\section{Hong Liu}

As one of the most prominent writers in Indonesia, Pramoedya Ananta Toer has been at the center of a number of valuable studies which carefully document his intellectual journey and his place in modern Indonesian cultural history. ${ }^{1}$ It has been generally agreed that the years between 1956 and 1959 were crucial in the evolution of Pramoedya's cultural and political thinking. In an effort to trace the causes of this change, the existing literature focuses almost exclusively on Indonesia's turbulent domestic political transformation and its impact on Pramoedya; very little attention

\footnotetext{
"This is an expanded version of a chapter from my doctoral dissertation, "The China Metaphor": Indonesian Intellectuals and the PRC, 1949-1965" (Ohio University, 1995). I am indebted to William H. Frederick for his constructive and thorough comments. Charles Alexander, Donald Jordan, Benedict Anderson, Chen Xiaru, Go Gien Tjwan, Kent Mulliner, Kohar Rony, Yong Mun-Cheong, and Tsing Yuan have been helpful in shaping my understanding of the complex questions relating to China in Indonesia, for which I am grateful. Financial support for my overseas research was provided by a fellowship from the Center for International Studies at Ohio University and a grant from the Southeast Asian Council of the Association for Asian Studies, both funded by the Henry Luce Foundation. I alone, of course, am responsible for the views expressed here and any remaining errors.

1 See for example, Bahrum Rangkuti, Pramoedya Ananta Toer dan Karja Seninja (Jakarta: Gunung Agung, 1963); Savitri Scherer, "From Culture to Politics: The Writings of Pramoedya Ananta Toer" (PhD diss., Australian National University, 1981); Mohamad Zamri bin Shaari, "Sebuah Analisa Kebahasaan terhadap Bumi Manusia Karya Pramoedya Ananta Toer" (PhD diss., Universitas Nasional Indonesia, 1985); and A. Teeuw, Pramoedya Ananta Toer de Verbeelding van Indonesie [Pramoedya Ananta Toer and the Imagining of Indonesia] (Breda: De Geus, 1993).
} 
120 Hong Liu

has been drawn to an important external source of inspiration that facilitated Pramoedya's shift to cultural leftism: his perceptions of China and of People's Republic of China (PRC) literary doctrines. A. Teeuw, an authority on modern Indonesian literature, is one of the few scholars who has noticed the critical connection between Pramoedya's attitude toward the PRC and his changing views regarding Indonesia. He argues that Pramoedya's 1956 trip to China represented a milestone: "It was only with his return from Peking that the dream of the poet was exchanged for the action of the social fighter." 2 However, Teeuw does not examine in any length why Pramoedya's China experience was so significant and how his perception of the PRC actually affected his thinking about Indonesia. The lack of close scrutiny on Pramoedya's complex perceptions of the PRC and their ramifications impedes a better comprehension of Pramoedya and his vital role in Indonesia's left-leaning cultural movement during the first half of the 1960s.

This paper discusses Pramoedya's understanding of the PRC's cultural principles and practices, and suggests how it is relevant to the evolution of his thought. It will be argued here that, in reformulating his agendas for Indonesia, Pramoedya consistently drew upon his favorable impressions of the PRC and the (perceived) respected role of Chinese intellectuals. His notion of what went wrong with Indonesia was constantly compared with his perception of what went right with the China example. In so doing, the China image constructed and presented by Pramoedya became a mirror and a metaphor which contained transformable implications of far-reaching significance beyond its original connotations. By using China as a political statement and a cultural symbol, Pramoedya in effect incorporated some key PRC literary doctrines into his modified visions for Indonesia, which in turn prompted his transition to cultural radicalism.

\footnotetext{
2 A. Teeuw, Modern Indonesian Literature, 2nd ed. (The Hague: Martinus Nijhoff, 1979), p. 167; Teeuw, Pramoedya, p. 36. Boen Oemarjati concurs, "Before it [the 1956 tripl Pramudya may be regarded to have written a kind of engageé literature. ... After his Peking visit he seemed to have developed himself to a kind of enrage writer." See her, "The Development of Indonesian Literature," in Dynamics of Indonesian History, eds. H. Soebadio and C. A. M. Sarvaas (Amsterdam: Elsevier/North Holland, 1978), pp. 327-28. According to Harry Aveling, Pramoedya was "captivated by the social and economic progress made by China. From that time [October 1956] on, Pramoedya became increasingly involved with left-wing cultural and literary activities in Indonesia." See Aveling, "Introduction," in Pramoedya, The Girl from the Coast (Singapore: Select Books, 1991), p. vi. But none of the authors elaborates his or her arguments or provides any documentation for his or her findings.
} 


\section{Pramoedya in the Pre-1956 Years: The Evolution of a Cultural Intellectual ${ }^{3}$}

\section{Pramoedya as a Writer of "Universal Humanism"}

Pramoedya Ananta Toer was born on February 6, 1925 in Blora, a small town in north-central Java. ${ }^{4}$ His father was headmaster of a Budi Utomo school. After completing his elementary school course of study, Pramoedya went to Surabaya to study at the Radio Vocational School in 1940. During the Japanese occupation (19411945), he attended an adult school while working at the Japanese Domei press agency. When the revolution broke out in 1945, he joined a pemuda (youth) paramilitary organization before entering the Siliwangi Division in East Java. Between July 1947 and December 1949, Pramoedya was imprisoned by the Dutch. After 1950 he became editor of the modern literature section at Balai Pustaka, a government publishing house, and of the Indonesia, a leading cultural journal. At the end of 1951, he left Balai Pustaka and founded DUTA, the Literary and Features Agency.

Pramoedya's thinking prior to 1956 had been characterized by its adherence to nationalism and universal humanism, which were clearly manifested in his Perburuan (The Fugitive) and Keluarga Gerilya (The Guerrilla Family), novels about anti-Japanese and anti-Dutch revolutionary movements. In addition to their patriotic and nationalist coloring, these two novels had a deep humanistic strain, which reflected the prevailing universal humanism of the time. One of the key maxims in this humanistic literary doctrine was the conviction that Indonesian writers were "the true heirs of world culture." The 1950 Testimonial of Beliefs (Gelanggang) declared, "Indonesian culture is determined by the combination of all sorts of stimulating voices which are caused by voices hurled from all corners of the world, to be hurled back later in the form of our own voice."5 As Pramoedya himself later wrote, "this novel [Keluarga Gerilya] too was inspired by patriotic semangat, and from another angle, by humanity [humanitas]-a utopian idealism that lives and dies by its rejection of existing reality." 6 This

\footnotetext{
${ }^{3}$ In my study of Indonesia's China perceivers during the Sukarno era, I divide them into two groups: political intellectuals and cultural intellectuals. Represented by individuals like Sukarno and Mohammad Hatta, the former group consisted of those who, while they assumed administrative or political responsibilities in the government or other political organizations, still maintained some broad intellectual concerns with themes and issues of enormous, intrinsic significance for postcolonial Indonesia. As creators and articulators of ideologies, their primary domain of activity was the "political market-place." Cultural intellectuals, on the other hand, were identical with the group of people who would be identified as "intellectuals" according to the standard Western definition of the term. Absent from direct responsibilities for practical affairs, they functioned principally as interpreters of the world, producers of ideas, and depositories of cultural values. For a fuller discussion, see Liu, "The China Metaphor," pp. 1418.

4 The biographical data is drawn from Pramoedya Ananta Toer, "Perburuan 1950 and Keluarga Gerilya 1950," trans. Benedict Anderson, Indonesia 36 (October 1983), pp. 25-48; and Boen Oemarjati, "The Development."

${ }^{5}$ A. Teeuw, Modern Indonesian Literature, p. 127. See also Savitri Scherer's discussion of the influence of universal humanism on Pramoedya, in her "From Culture to Politics," pp. 130-31.

6 Pramoedya, "Perburuan 1950," p. 38. On Pramoedya's early novels, see the provocative analyses in Benedict Anderson, "Reading 'Revenge' by Pramoedya Ananta Toer (1978-1982)," in Writing on the Tongue, ed. A. L. Becker (Ann Arbor: Center for South and Southeast Asian Studies, University of Michigan, 1989), pp. 13-94; see also Keith Foulcher, "The Early Fiction of Pramoedya Ananta Toer, 1946-
} 
humanistic concern was perhaps partly responsible for Pramoedya's antagonism toward the Indonesian communists. His Keluarga Gerilya, for example, condemned not only the Dutch and the English (for bombing Surabaya), but the communists for staging the bloody Madiun Rebellion. His other writings in the early 1950s continued to expound the frustrating theme of "the universal loneliness of man."7

Pramoedya's mode of thinking was in part shaped by a versatile political and cultural scene at home. The first years of the 1950s witnessed a persistent search for a political formula that would fit Indonesian circumstances. Deep-seated social and political divisions within the new-born Republic, however, made this task arduous, if not impossible. As a consequence, political instability, cultural antagonism, and ethnic/regional confrontation became conspicuous features of the early history of postcolonial Indonesia. ${ }^{8}$ It was within this context that disillusionment and alienation gradually replaced optimism and high expectations as the dominant mood of many intellectuals. The most obvious indication of this intellectual discontent was the frequent emergence of the notion of "crisis" in the political and cultural discourse. The 1953-1955 "crisis in literature" debates, for example, centered around three major themes: ${ }^{9}$ this crisis was a consequence of a failed revolution, it was partly generated by negative Western influence on Indonesian literature, and intellectuals' isolation from the people further aggravated the existing crisis. Pramoedya himself participated in these debates and agreed with most of the opinions expressed by frustrated participants.

Pramoedya left for the Netherlands in June 1953, perhaps intending to escape the gloomy scene of Indonesia and look for inspiration from the outside world. However, his six-month stay in Amsterdam as a guest of the Sticusa (Dutch Foundation for Cultural Cooperation) turned out to be fruitless. The Holland trip appears to have been a disappointment for Pramoedya, primarily because he came to recognize that Indonesia and the Netherlands were simply too different. Holland reminded him of "a coffin," and he was particularly sensitive to "the contrast between his own country, in the process of establishing itself and seeking an identity, and Holland which had already been established." 10 He became more critical of the West and charged that the

1949," in Text/Politics in Island Southeast Asia, ed. D. M. Roskies (Athens: Ohio University Southeast Asia Series, 1993), pp. 191-220.

7 Anthony Johns, "Pramudya Ananta Tur: The Writer as Outsider: The Indonesian Example," in idem, Cultural Options and the Role of Tradition (Canberra: Australian National University Press, 1979), pp. 96-108. See also Pramoedya, "Ada Humanisme di Oranje Nasaulaan-5 dan Komunisme telah Mati Bersama Lenin," Medan Bahasa 3, 10 (October 1953): 29-32.

8 The most comprehensive study of the Indonesian political history between 1950 and 1957 is Herbert Feith's The Decline of Constitutional Democracy in Indonesia (Ithaca: Cornell University Press, 1962). On some of the more recent insightful observations, see David Bouchier and John Legge, eds., Democracy in Indonesia: 1950s and 1990s (Clayton: Centre of Southeast Asian Studies, Monash University, 1994).

${ }^{9}$ See Liu, "The China Metaphor," pp. 158-163.

10 Teeuw, Modern Indonesian Literature, p. 166. According to Willard Hanna, Pramoedya's disappointment in Holland was mainly the result of personal problems: "He did not receive sufficient financial support to enable him live or travel as he wished; he did not meet many Dutch persons of prominence, literary or otherwise; and he did not find any appropriate opportunity for study." See Hanna, "Guerrilla Family': A Novel of the Indonesian Revolution," American Universities Field Staff(Southeast Asia Series) 5, 14 (September 12, 1957): 8. 
Sticusa was a "colonial brain trust" which only aimed at "importing Western culture into Indonesia." 11 While in Holland, Pramoedya was perhaps influenced by a leading Dutch Indonesian specialist, W. F. Wertheim, who held that the root of confusion in Indonesian literature lay in "the failure of the Indonesian revolution as a social revolution." 12 After coming back to Indonesia, Pramoedya's disillusionment was exacerbated by rampant corruption and social chaos. As he later recalled those days, "I saw that all the promises of the revolution had been left unfulfilled." 13 His literary probing to penetrate to the heart of human problems appeared to have taken him nowhere. In mid-1956, he published a story entitled "Silence at Life's Noon," which vividly depicted the themes of intellectual alienation and resentment of Western cultural intrusion. According to Teeuw, this novel had symbolic meanings,

In this story the writer seemed to have reached a stage where he is ready to replace his dreams with action-he has reached this stage because of his embitterment with the world around him, and also because of his disappointment at the futility of his own life, at the failure of his writing and the insufficiency of his humanity. ${ }^{14}$

Breaking with the past, however, did not necessarily mean finding a new direction. In mid-1956 Pramoedya remained uncertain as to what he could do, as a marginalized writer, to combat social injustice and to help realize the dream of "a just and prosperous society." It was at this critical conjunction that he embarked on a trip to China, a trip that would profoundly affect his cultural and political thought.

\section{Pramoedya's Understanding of China: The Initial Stage}

Prior to his 1956 trip to China, Pramoedya had acquired some knowledge about that country and the PRC's cultural doctrines. While working for the Domei press agency during World War II, he was assigned by Adam Malik to cover the SinoJapanese war. ${ }^{15}$ By Pramoedya's own account, the activities of the Chinese communist army, Mao Tse-tung, and Zhou Enlai had been widely reported in Indonesia's "revolutionary newspapers" before independence. ${ }^{16}$ When he was jailed in Bukitduri

11 "Pramoedya tentang STICUSA," Kompas 5, 6 (1954): 55.

12 See Pramoedya, "Prof. Dr. Wertheim tentang Kesasteraan Indonesia Modern," Medan Bahasa 3, 11 (1953): 39-43. Pramoedya and Wertheim have remained in close contact ever since, with Pramoedya being the recipient of the 1995 Wertheim Prize. I am grateful to Dr. Go Gien Tjwan, Vice Chairman of the Wertheim Foundation, for providing me with the Testimonial of the Award (Leiden, August 15, 1995) and the information regarding the process of Pramoedya's nomination.

13 Cited in Margaret Scott, "Waging War with Words," Far Eastern Economic Review, August 9, 1990, p. 27. It has been pointed out that one of the major concerns in Pramoedya's writings during the first half of the 1950s was the question of "how did we get into this mess?" See Patricia Henry, "The Writer's Responsibility: A Preliminary Look at the Depiction and Construction of Indonesia in the Works of Pramoedya Ananta Toer," Crossroads 6 (1991), pp. 59-72.

14 Teeuw, Modern Indonesian Literature, p. 178.

15 Pramoedya," Perburuan 1950," pp. 34-35.

16 Pu Ananda Duer [Pramoedya Ananta Toer], "Jiaqiang Yin Zhong Youyi, Fensui mei Ying Qinlue" [Strengthening Sino-Indonesian friendship, resisting the aggression of the British and the Americans], Zhong Cheng Bao (Warta Bhakti) (Jakarta), October 1, 1964. Regarding writings about China published in pre-1949 Indonesia, see Claudine Salmon, Literature in Malay by the Chinese of Indonesia: A Provisional Annotated Bibliography (Paris: Editions de la Maison des Sciences de l'Homme, 1981), pp. 66-67, 75-76; Kwee Kek Beng, Doea Poeloe Lima Tahoen Sebagai Wartawan, 1922-1947 (Batavia: Kuo, 1948), pp. 32-43; and 
124 Hong Liu

in 1948, Pramoedya recorded, he met a Dutch prisoner who was a former officer of the Royal Netherlands Indies Army (KNIL). The Dutchman told Pramoedya that he had been sentenced to death. "However," he said to Pramoedya, "I still have a glimmer of hope; if the Chinese Red Army advances southward, I will be saved." Since that time, Pramoedya recalled, "I have developed a feeling that the influence of the Chinese Red Army has been so far-reaching, it even penetrates to the hearts of Dutch soldiers ... and it has left some tangible stimulating effects [on the Indonesians]."17

During the first half of the 1950s, Pramoedya started paying some attention to the Chinese cultural practices. In his 1952 essay, "Literature as a Tool," Pramoedya cited Mao Tse-tung's work to support his own view that literature was nothing but a tool people used to achieve their own agendas. He displayed an ambivalent attitude toward Mao's principle that "art should serve the people, especially the workers, peasants, and soldiers." He contrasted this stance with the "aristocratic view" that art was for those who understood (which he did not reject). Pramoedya found merits and deficiencies in both opinions: the first [the aristocratic] view was capable of preserving creative integrity whereas the second [Mao's] view had the power to eradicate a possible decadent creation that might imperil social unity. ${ }^{18}$ In 1954 , Pramoedya translated, from an English or Dutch source, an article by Zhou Yang [Tjau Jang], ${ }^{19}$ the Chinese cultural czar. In this essay, entitled "Socialist Realism--The Road of Advance for Chinese Literature," 20 Zhou Yang argued that Chinese literature needed its own national character and needed to be open to all progressive influences. He also elaborated some principles of socialist realism and called for a "class perspective" in portraying real life. By the mid-1950s, Pramoedya had developed a certain degree of admiration for what he perceived the high social status of writers in socialist nations such as the PRC, "where literature is considered to be one of the political and economic forces" and where writers were paid generously for their publications, in a stark contrast to conditions in Indonesia. ${ }^{21}$

During the 1955 Bandung Conference, Pramoedya had some contact with the Chinese delegation and the Chinese embassy, which may be taken as an indication of

Wu Wenhua \& Gan Meifeng, "Benshiji Sanshi dao Wushi Niandai Huawen Tushu zai Yinni," [Chinese books in Indonesia from the 1930s to the 1950s], Dongnanya Zongheng 3 (1993): 41-46.

$17 \mathrm{Pu}$ Ananda Duer, "Jiaqiang." There is perhaps some factual basis for this Dutchman's assertion. In 1948/49, a few Pesindo units in East and West Java named themselves as "Mao Tse-tung Brigades" and wanted to be united with the Chinese Red Army. See Jacques Leclerc, "Aidit dan Partai pada tahun 1950," Prisma 7 (1982): 61-78.

18 "Kesusteraan sebagai Alat," Indonesia 3, 7 (1952): 6-11.

19 With a few exceptions (such as "Peking" and "Mao Tse-tung"), this paper employs the Pinyin system for the romanization of Chinese terms. For reference purpose, the original Indonesian translation of Chinese terms is included in the bracket. See the appendix of this article for a complete list of crossreferences.

20 "Realisme Sosialis_Jalan Kemajuan bagi Kesusastraan Tionghoa," Harian Rakjat, May 8, 1954. This essay was originally published in the Flag, a Soviet literary journal, in December 1952 and reprinted in Zhou Yang Wen Ji [Collected essays of Zhou Yang], vol. 2 (Peking: Renmin Wenxue Chubanshe, 1985), 182191. The English version appears in Chou Yang [Zhou Yang], China's New Literature and Art: Essays and Addresses (Peking: Foreign Language Press, 1954).

21 Pramoedya, "Hidup dan Kerdja Sasterawan Indonesia Modern," Seni 1, 1 (1955): 22-36. 
his increasing interest in the PRC. ${ }^{22}$ In early 1956 Pramoedya translated, perhaps from English, a long article by Ding Ling [Ting Ling], one of the most prominent writers in China. ${ }^{23}$ This translation, entitled "Life and Creative Writing," appeared in the cultural journal, Indonesia. ${ }^{24}$ Central to Ding Ling's thinking was the idea that a good literary and artistic work could only be generated by concrete life experience. In order to produce valuable works, writers must "go into the life and live with the people." Only after understanding that they were "writing for workers, peasants, and soldiers," argued Ding Ling, could writers be truly integrated into the masses. Pramoedya seemed to be somewhat convinced by her arguments. In an essay published three months later, he echoed Ding Ling's views by suggesting that writers should come and live among the people and that they should directly participate in industrial production. ${ }^{25}$ Pramoedya's writings prior to October 1956 indicated that he had read widely, from Dutch and English sources, on the literature of the PRC and was very familiar with works of major PRC writers (such as Guo Moruo [Kuo Mo-jo], Ding Ling, and Mao Dun [Mao Tun]). In a July 1956 essay, he praised the PRC government for its endeavors in promoting culture and education. He considered Mao Dun and Lu Xun [Lu Hsun] to be "two of the best and most famous writers in China, because they belonged to the new generation who is conscious of its social responsibilities." 26 By mid-1956, Pramoedya had also completed the translation of some portions of Diary of a Madman (Catatan Orang Gila), a novel by Lu Xun. ${ }^{27}$

Pramoedya in the mid-1950s was at the crossroads. His conviction that the Indonesian revolution had failed, together with what he perceived to be the gloomy realities of his own country, was the major cause behind his frustration and disillusionment. Universal humanism had proved to be ineffectual in confronting the enormous social and political problems facing the Indonesian nation. He longed for greater social recognition and a more active role for intellectuals, and he was deeply

\footnotetext{
22 Interview with Chen Xiaru, January 29, 1994, New York. Ms. Chen was an Indonesian-language interpreter of the Chinese Writers' Union, which hosted Pramoedya during his 1956 and 1958 trips to China.

23 Ding Ling, vice chair of the Chinese Writers' Union during the early 1950s, won the Stalin Prize in 1951 for her novel on land reform, The Sun Shines on the Sanggan River. On her career and writings, see Yi-tsi Mei Feuerwerker, Ding Ling's Fiction: Ideology and Narrative in Modern Chinese Literature (Cambridge: Harvard University Press, 1982).

24 "Hidup dan Penulisan Kreatif," Indonesia 7, 3 (March 1956): 102-110. The original essay was entitled "Dao Qunzhong Zhong Qu Luofu" [To Settle in among the masses], which was the text of a speech delivered to the Second National Conference of Chinese Cultural Workers held in September 1953. It is reprinted in Ding Ling Wen Ji [Collected essays of Ding Ling] vol. 6 (Changsha: Hunan Renmin Chubanshe, 1984), pp. 176-188.

25 Pramoedya, "Meninggalkan Negativisme," Mimbar Indonesia 10, 22/23 (June 9, 1956): 15, 26.

26 Pramoedya, "Manakah Pengarang dari Golongan Keturunan Tionghoa," Pendorong, July 13, 1956. See also Pramoedya, "Sedikit tentang Kesusasteraan Tionghoa di Indonesia," Pantja Warna 15, 113 (April 15, 1957): 85-86. I am grateful to Dr. Martina Heinschke of the University of Hamburg for making available these essays and some other writings of Pramoedya to me from her own research materials collection.

27 "Duer Fanwen Ji" [An interview with Toer], Hsin Pao (Jakarta), November 17, 1956. [Hsin Pao was the Chinese version of the $\operatorname{Sin}$ Po, one of the most widely read newspapers during the 1950s]. Diary of $a$ Madman (1918), which catapulted Lu Xun to nationwide prominence as a writer and leader of the "New Literature," signaled "the first instance of Lu Xun's radical epistemology." See Leo Ou-fan Lee, Voices from the Iron House: A Study of Lu Xun (Bloomington: Indiana University Press, 1987), p. 54.
} 
126 Hong Liu

disappointed at the lack of organization and poor financial conditions of Indonesian writers. ${ }^{28} \mathrm{His}$ distrust of communism prevented him from joining the leftist cultural organization, Lekra. As a consequence, the pre-1956 Pramoedya remained a detached intellectual painfully searching for a new direction. Furthermore, his experience in the Netherlands convinced him that Western culture could not provide any useful solutions for Indonesia's problems. He began to look elsewhere for answers. It was within this context that China entered the domain of Pramoedya's (re)construction of his literary precept and political ideology; the PRC soon acquired a metaphorical status, as a reference point reflecting his perceptions of what had gone wrong with Indonesia. His translation of Chinese literary work indicated that he was somewhat attracted to the PRC's cultural practices. In fact, Pramoedya might have found a convergence between his own cultural outlook and PRC literary doctrines. For example, both shared a concern for the fate of the masses, though for Pramoedya, they represented socially undifferentiated "little people," and for PRC writers, the masses were members of the working class, namely, peasants, workers, and soldiers.

\section{Experiencing a New World: Pramoedya Ananta Toer in China}

\section{The Politics of Invitation}

Pramoedya embarked on a one-month trip to the PRC in October 1956. The invitation was forwarded to him by three prominent Chinese cultural and political figures: Guo Moruo, chair of the All-China Federation of Literary and Art Circles (AFLAC) and president of the Chinese Academy of Sciences; Mao Dun, chair of the Writers' Union; and Chu 'Tunan, head of the Association of the Chinese People's Cultural Exchange with Foreign Countries, a major arm of China's cultural diplomacy. Pramoedya was invited to attend a conference commemorating the twentieth anniversary of Lu Xun's death and to visit some Chinese cities.

Why was Pramoedya invited to China? Although he was apparently one of the most renowned writers in Indonesia, he was by no means pro-communist in terms of his political and cultural orientation. In fact, his negative description of the communist terror in his earlier novels might very well have alienated some communist party members. According to an official internal document, compiled from the materials provided by the Chinese Embassy in Jakarta, Pramoedya in the mid-1950s, together with individuals such as Rivai Apin and Utuy Sontani, was classified as a "petitbourgeois Centrist Writer." Unlike "the Rightists" (e.g., Takdir Alisjahbana and Trisno Sumardjo) and "the Leftists" (e.g., Lekra-associated writers), "Centrist Writers" accounted for the largest group among Indonesian intellectuals and they were characterized by

their frustration and aimlessness. They were unwilling to throw in their lot with the imperialists; yet they did not have the courage to join the struggle of the people and to be part of the Indonesian revolutionary cause. They were dissatisfied with realities, corruption and weakness of the capitalist regime, and they wanted the status quo changed. However, they lacked a clear awareness of the arduous and prolonged nature of the national revolution, or they did not have

28 Pramoedya, “Kegiatan Seni dalam Bulan September di Ibukota,” Pudjangga Baru 14, 3 (1952): 65-67. 
sufficient confidence [in this revolution]. As a consequence, they held harsh and extreme sentiments toward the existing social and political order. ${ }^{29}$

There were perhaps two major reasons for inviting Pramoedya to visit the PRC. First, it was a principle of the Chinese cultural exchange policy to invite foreign intellectuals with centrist or rightist orientations to visit China. The rationale behind this policy was the hope that those intellectuals would be impressed by China's progress, and that their favorable observations regarding the PRC would in turn produce greater effects upon public opinion in their home countries. During his tenure as Chinese ambassador to Indonesia between 1954 and 1960, Huang Zhen energetically and effectively pursued this cultural diplomacy. ${ }^{30}$ The second reason for inviting Pramoedya was more complex and should be discussed within the Indonesian domestic context. By the mid-1950s, political conflict in the cultural sphere had been intensified, primarily as a result of Lekra's expansion. Established in 1950 and closely associated with the Communist Party of Indonesia (PKI), Lekra advocated the principle of "art for the people" and vigorously sought to expand its horizon during the mid-1950s. It was reported that by 1956 the Lekra leadership had been "working on" Pramoedya, hoping to gain his support and sympathy for the left-leaning cultural movement. ${ }^{31}$ According to some sources, it was Lekra that first suggested to the Chinese embassy that Pramoedya be invited to China. The embassy then made the recommendation to the respective Chinese authorities in Peking. ${ }^{32}$

\section{Pramoedya in China: 1956}

Pramoedya arrived in Peking in mid-October. Before leaving for China, he had conceived of this trip as a valuable opportunity for formulating his thought not only about China, but more importantly, about Indonesia. As he recalled later,

\footnotetext{
${ }^{29}$ Duiwai Wenhua Lianluo Weiyuanhui Ersi [The Second Bureau of the Committee of Cultural Liaisons with Foreign Countries], comp., Yindunixiya Wenhua Gaikuang [A survey of Indonesian culture] (Peking: for internal circulation only, 1962), pp. 5-6.

${ }^{30}$ Teng Yun, ed., Dangdai Zhongwai Wenhua ]iaoliu Shiliao [Historical materials on cultural exchanges between China and foreign countries in the contemporary era] (Peking: Wenhua Yishu Chubanshe, 1990), passim. On ambassador Huang Zhen's efforts in Indonesia, see two recently published accounts (by his successor and his wife, respectively), Yao Zhongming, et al., Jiangjun, Waijiaojia, Yishujia-Huang Zhen Jilian Wenji [General, diplomat, and artist-A collection of essays in commemorating Huang Zhen] (Peking: Jiefangjun Chubanshe, 1992); and Zhu Lin, Dashi Furen Huiyilu: Xunyali, Yinni, Faguo, Meiguo [Memoir of an ambassador's wife: Hungary, Indonesia, France, and the USA] (Peking: Shijie Zhishi Chubanshe, 1991).

31 Interview with Shannu, July 8, 1994, Peking. Shannu, an Indonesian-Chinese writer who knows Pramoedya personally and was close to Lekra, stated that the PKI Politburo member Njoto personally talked to Pramoedya. According to a Chinese official working in the Cultural Section of the Chinese embassy in Jakarta (who wishes to remain anonymous), Joebaar Ajoeb, secretary general of Lekra, mentioned a number of times that they "were making efforts" on the person of Pramoedya. (Interview in Peking, June 29, 1994). In an interview with the journalist Salim Said, Pramoedya revealed that Lekra started approaching him in 1956. See "Saya Lebih Percaya Kepada Kemanusiaan," Tempo, December 31 , 1977, pp. 8-11.

32 Interviews with Chen Xiaru, January 29, 1994; Huang Shuhai (an official of the Chinese embassy in Jakarta and later of the Ministry of Foreign Affairs in Peking), July 1993, Washington DC; and with an anonymous Chinese official who worked in the Cultural Section of the Chinese embassy in Jakarta, June 29, 1994, Peking.
} 
128 Hong Liu

When visiting a foreign country, there were two things I had to pay attention to. If I went to a developed country, there was no question. But in a new nation, I had to study, because there were definitely similarities in terms of how to better the fate of the country and the people. China was one of these new nations. If I was influenced by the PRC, it was by itself, because it was a new nation that had already established itself. Indonesia was also a new nation. . . . There must be certain resemblances between new nations. There was something to be learned from and some good examples be taken. Indeed, just look at the PRC at that time, it was much more successful than Indonesia. ${ }^{33}$

Pramoedya's first major activity in China was participating in the conference commemorating the twentieth anniversary of Lu Xun's death, which was a wellpublicized event attended by writers from more than twenty countries. Clearly aware of the appeal of Lu Xun to intellectuals of the newly independent nations, both Guo Moruo and Mao Dun emphasized in their respective keynote speeches that the greatness of Lu Xun derived from "his revolutionary thinking and from his devotion to the people." Guo Moruo reassured his foreign guests that PRC intellectuals would "live up to the expectations of cultural workers of other countries-that is, the new culture of the PRC would make greater contributions to the world culture and China would produce more Lu Xuns." 34 As one of the foreign guests invited to speak to the conference, Pramoedya praised Lu Xun as a great writer whose contributions lay not only in his insightful observation of society, but more importantly, in his willingness and ability to struggle for improving the fate of the masses. "Lu Xun was the voice of his nation and his people," Pramoedya continued, "Lu Xun was an embodiment of the moral awakening which was full of noble hopes for human beings. He did not merely hope, he took the best and most appropriate method-literature-in the endeavor for realizing his ideals." 35 This Lu Xun as understood by Pramoedya clearly reignited his own aspiration for Indonesian intellectuals,

Every writer has responsibilities, and it is because of these responsibilities that choices have to be made. Lu Xun chose to be on the side of the people who suffered from hardship and misery. ... . He not only made choices, but fought to ensure his ideals be realized. He was a realist in thinking and a realist in action. ${ }^{36}$

This idea of combining thinking and action provided the most relevant model in Pramoedya's ardent search for effective solutions to Indonesia's social and cultural problems. And Lu Xun as presented in the light of official Chinese interpretation apparently cast an impact upon Pramoedya's views. After returning to Indonesia, Pramoedya characterized Lu Xun not only as a great intellectual, but as a fighter who was "the father of China's socialist realism."37

33 "Wawancara: Pramoedya, Bakal Pemenang Hadiah Nobel," Nadi Insan (Kuala Lumpur) 24 (April 1981): 8.

34 See the texts of their speeches, in Wenyi Bao (Peking), 20 (1956): 4-10.

35 "Yindunixiya Zuojia Pulamudiya Ananda Duer de Jianghua" [Speech by the Indonesian writer Pramoedya Ananta Toer] Wenyi Bao 20 (1956): 15-16.

36 Ibid., p. 16.

${ }^{37}$ Pramoedya, “Sedikit tentang Kesasteraan Tionghoa di Indonesia," p. 86. 
After the Peking conference, Pramoedya visited Shanghai, Nanking, and Canton. He told an Indonesian reporter that compared with his experience in Europe, he found it much easier to establish cordial contact with the Chinese and he felt very happy with his stay in China. ${ }^{38}$ While in China, Pramoedya had some extended meetings with a number of prominent Chinese writers and cultural officials, among them Zhou Yang, Mao Dun, Ba Ren (Wang Renshu, a writer and literary critic, who was the first Chinese ambassador to Indonesia and then the head of the People's Publishing House), Yang Shuo, Liu Baiyu, Liu Zhixia, Guo Xiaochuan, and Li Rui (who was appointed Mao Tsetung's personal secretary two years later). ${ }^{39}$ These meetings took place in an amiable atmosphere and a line of communication between Pramoedya and these Chinese writers was quickly established. (On one occasion, Pramoedya and his hosts even continued their zealous discussion after the dinner, without prior schedule, at Ba Ren's residence.) Two major themes emerged in these meetings. ${ }^{40}$ The first was the PRC literary doctrine of "socialist realism," which originated in the Soviet Union but had been largely localized by Mao Tse-tung and his cultural theoreticians. (Lu Xun, for example, was hailed by the Chinese as "a great pioneer and representative of socialist realism.") Central to this literary doctrine was the conviction that artistic works should reflect social realities and the life of the people. The Chinese writers also spent a substantial amount of time debunking the notion of "art for the sake of art." The second theme, "art should serve the people," was first systematically elaborated by Mao Tse-tung in his 1940 Talk at the Yenan Forum on Literature and Art. ${ }^{41}$ As indicated earlier, Pramoedya had exhibited a certain degree of familiarity with and ambivalent admiration for both principles. His discussions with the PRC architects of "socialist realism" and "art serving the people" were likely to enhance his understanding and, perhaps a greater appreciation, of these literary doctrines.

Pramoedya's impressions from his first China trip were overwhelming. He was fascinated by China's rapid social and economic progress and believed that this progress was made possible by the Chinese people, who "are making history." 42 What was important for the Chinese people was "not money, profit, and loss," Pramoedya suggested, "but sincerity, consciousness, and work." 43 He seemed to have been amazed by the Chinese, who possessed simultaneously the spirit of "romanticism and pragmatism" and who worked not for individual, but national and societal interests. ${ }^{44}$ He described China as "an epic in the making" and the Chinese revolution as "a total revolution" instead of a reform. ${ }^{45}$ Like many other Indonesian China perceivers who visited the PRC during the 1950s, Pramoedya depicted a favorable China image as a contrast to his own nation: "In Indonesia, people only think of themselves; over there,

38 "Pramudya Ananta Tur di RRT," Sin Tjun 2 (1957): 107.

${ }^{39} \mathrm{Hsin}$ Pao, November 17, 1956; interview with Chen Xiaru (who was present in most of these meetings), February 13, 1994.

40 Interviews with Chen Xiaru, February 13 and September 20, 1994.

41 Mao Tse-Tung, Talk at the Yenan Forum on Literature and Art (Peking: Foreign Language Press, 1965).

42 Pramoedya, "Suatu Kali di Tiongkok," Tiongkok Rakjat 7 (July 1958): 40-41.

43 Cited in Bahrum Rangkuti, Pramoedya, p. 21.

44 "Pramudya Ananta Tur di RRT," p. 107; and Pramoedya, "Suatu Kali," p. 41.

45 Pramoedya Ananta Toer, "Djiwa Revolusioner di Tiongkok Tetap Bergolak," Sin Po, January 5, 1957. 
130 Hong Liu

everyone thinks of others. Here, people have to be greedy in order to survive; over there, the greedy instinct has been annulled and totally eliminated." 46

As a writer, Pramoedya was particularly interested in the relationship between intellectuals and society in the PRC. As noted earlier, it was one of the central issues Pramoedya had tried to come to grips with. The Chinese practice provided him with not only a mirror reflecting what went wrong in Indonesia, but a viable model for what ought to be done. One of Pramoedya's favorable observations regarding China was the high social and political status of writers and artists. He wrote,

Chinese writers occupy a high place. Their voices are heard by the society. Together with politicians, they constitute the spiritual leaders, who hold an extremely important role in the nation building of our age. This helps explain why writers are very well treated by the society. ${ }^{47}$

According to Pramoedya, one indication of Chinese writers' high social status was the generous financial rewards they received for their publications. "One thing that attracts much of my attention as a writer is the security of life enjoyed by writers in the new China," he commented, "over there, a writer can lead a decent life from his pen." $48 \mathrm{He}$ reported that Liu Zhixia [Liu Tje Sie] was paid RMB 400,000 as remuneration for his novel Railway Guerrilla. This was certainly not small change. "It is approximately 240 times of a Chinese cabinet minister's monthly salary," Pramoedya marveled, "in other words, Liu can live on a living standard of a minister for 20 years, just because of one novel." 49 This material reward for Chinese writers exemplified that "Chinese culture is supported by the highest authorities."

Underlying Pramoedya's enthusiastic description of Chinese writers' enviable social status was the implicit acknowledgment that PRC practices were in effect a realization of his own ideals for Indonesia. Prior to 1956, Pramoedya had complained repeatedly the low economic rewards Indonesian writers received from their creative work. ${ }^{50}$ He had called for greater respect for writers, who should be rewarded in accordance with their creative status. On the other hand, PRC practices made Pramoedya realize that the social and political status of intellectuals was contingent upon their contributions to the nation. He was convinced that Chinese writers' high respectability was a direct result of their involvement in political transformation. Pramoedya felt strongly that Chinese writers set an example in understanding society and the current situation rather than being occupied with their own egotistical interests. ${ }^{51}$ In other words, Pramoedya came to the critical understanding that in order to raise their own position, intellectuals should first actively participate in the social

\footnotetext{
46 Ibid.

47 Pramoedya, "Sedikit tentang Pengarang Tiongkok," Mimbar Indonesia 3 (January 19, 1957): 21.

48 "Pramudya Ananta Tur di RRT," p. 107.

49 Ibid. See also Hsin Pao, November 17, 1956.

${ }^{50}$ Pramoedya noted that while Chinese writers were paid Rp. 1,000-3,000 for every three pages of their writings, Indonesian writers got only Rp. 30 per short story. In order to barely survive, Indonesian writers had to publish at least ten stories every month and they often had to seek other part-time employment. See Pramoedya, "Hidup dan Kerdja," and Pramoedya, "Keadaan Sosial Para Pengarang: Perbandingan Antarnegara," Siasat 11, 506 (January 20, 1957): 28.

51 Pramoedya, "Kearah Sastera Revolusioner," Star Weekly 574 (December 29, 1956): 6-7.
} 
and political process. The attitude of a detached bystander could only further jeopardize writers' position in society.

The China trip also provided Pramoedya with opportunities to study methods of organizing writers in their efforts to partake in the nation-building process. Before going to China, Pramoedya had advocated that writers needed to be organized in the combat against examples of a decadent social atmosphere (such as corruption). Yet he was very disappointed at the lack of effective organization, which he thought was a major difficulty facing Indonesian intellectuals. ${ }^{52}$ His meetings with Chinese cultural officials, especially Mao Dun, chairman of the Writers' Union, might have given him some concrete examples as to how to organize writers. Shortly after returning to Indonesia, Pramoedya wrote an essay detailing the role of the Writers' Union. He discussed five major functions of the Writers' Union and the methods of achieving its goals. These functions ranged from "organizing writers to participate in and experience life" to "conducting cultural exchanges with the progressive countries."53 Pramoedya's admiration for the integration of Chinese writers into society had a bearing on his evaluation of Chinese literary works. As noted earlier, Pramoedya's previous attitude toward the two extremes of cultural perspectives-“art for the art's sake" and "art for the people" — had been ambivalent. However, after the end of 1956, he came to place a greater preference for the latter. According to Pramoedya,

Seen from the stand-point of international literature, China's literary works are somewhat formalistic. However, seen from the perspective of the [Chinese] state, there is no reason for much criticism, because China is now in the process of massive construction; writers write for the purpose of educating the masses rather than for money. ${ }^{54}$

\section{Pramoedya in China: 1958}

Pramoedya made his second trip to China in late October 1958. By this time, it was a new Pramoedya, mainly because of the transformation of his cultural and political thought following his return from China in November 1956 (see below). China was also different at this time; the start of the Great Leap Forward and the People's Commune movements changed the landscape of the country and the moods of the people. Consequently, Pramoedya looked at this new China from a new political and cultural perspective. China continued to be a source of inspiration, and his second trip accelerated the process of his shift to cultural radicalism.

Pramoedya's second visit was in conjunction with the Asian and African Writers' Conference held in Tashkent, the Soviet Union. After the conference Pramoedya, who was the head of the Indonesian delegation, returned home via China. During this trip, which lasted approximately one month, he visited the cities of Peking, Wuhan, Chengdu, and Kunming. By this time, the Chinese authorities no longer considered Pramoedya to be an "aimless and frustrated writer." Instead, he was regarded as a representative of those formerly "centrist writers" who started disassociating themselves from "the camp of illusion" and joining the leftist "nationalist and

\footnotetext{
52 Pramoedya, "Kegiatan Seni."

53 Pramoedya, "Sedikit tentang Pengarang Tiongkok," pp. 20-21.

${ }^{54} \mathrm{H} \sin$ Pao, November 17, 1956.
} 
democratic front." 55 By the time of Pramoedya's arrival, it had been decided by the Chinese Writers' Union, the host of Pramoedya's 1958 party, that there would be three central themes in the discussions and meetings with the Indonesian visitors. ${ }^{56}$ The first was that "the American imperialists are paper tigers," who would be defeated if the people united in their struggle against imperialism. The second theme was the propagation of China's experiences and achievements in carrying out massive economic development. The third theme was the principle of "politics is the commander" in the cultural sphere. Other topics also emerged in Pramoedya's meetings with Chinese writers and cultural officials. Zhou Yang, for instance, spoke of the new Chinese cultural doctrine of "revolutionary romanticism," 57 while other Chinese emphasized that "writers must follow Mao Tse-tung's road." Therefore, compared with the 1956 discussions, the 1958 ones were much more politicized. Pramoedya appears to have taken these topics seriously and have agreed with the Chinese on major issues discussed. ${ }^{58}$

By 1958 Pramoedya was no longer a detached observer but an active participant. During his first China trip, his attitude toward art and intellectuals' social role had been ambivalent, his perceptions of China primarily characterized by the sense of amazement and admiration. The second China trip evoked in him an appreciation of profound political implications, and he openly expressed his political opinions on a variety of matters. In other words, Pramoedya's China became a political rather than a cultural symbol. He continued to praise the role of Chinese writers as "engineers of the human spirit." More frequently, however, he was concerned with politics and the political implications of the PRC. For example, colonialism and imperialism constituted the central aspects of his criticisms of Western influence. He called for the establishment of a united front, centered in Peking ("a symbol of Asia and Africa"), in the struggle against imperialism and colonialism. ${ }^{59}$ Pramoedya's views of art and its relation to society were no longer ambiguous. He stated clearly that art should be responsible to the people. Writers should be not only the conscience of society, but also participants in the battle on the front line. ${ }^{60}$ Pramoedya's second China trip apparently enhanced his admiration for the Chinese people and further convinced him of the need to learn from the PRC, as he wrote in late 1959,

Frankly, I admire the tenacity, skillfulness, industriousness, honesty, and revolutionary characteristics of the Chinese People. Indonesian people, not bourgeois, can learn a great deal from China, especially in terms of nation building. Never in history has such a gigantic construction happened within so

\footnotetext{
55 Yindunixiya Wenhua Gaikuang, p. 7.

56 Interview with Chen Xiaru, February 13, 1994.

57 This combination of "revolutionary realism and revolutionary romanticism and socialist realism" was first elaborated by Zhou Yang in mid-1958 and represented the Chinese attempt to replace the Russianoriginated concept of "socialist realism." It was also a reflection of widening Sino-Soviet rifts of the time. See for details in D. W. Fokkema, Literary Doctrine in China and Soviet Influence, 1956-1960 (The Hague: Mouton, 1965), pp. 196-201.

58 Interview with Chen Xiaru, February 13, 1994.

${ }^{59}$ Pramoedya, "Tasjkent-Peking," Tiongkok Rakjat 1 (January 1959): 48-50.

60 Ibid.
} 
short a time. Such a revolution has changed the face of the earth and human beings! And this is the People's Republic of China. ${ }^{61}$

As an active participant, Pramoedya attempted to draw certain practical examples from Chinese writers' involvement in social and political change. His participation in the "steel-making" process is a case in point. As mentioned earlier, 1958 was the beginning of China's Great Leap Forward movement, which was characterized by collective utopianism and a nationwide optimism. One of the vital goals of this movement was to produce $3,000,000$ tons of steel in 1959, which was one dimension of the efforts at "surpassing the British and catching up with the Americans" in the industrial field. Chinese intellectuals took part, on a massive scale, in this primitive steel-making, which utilized something like backyard blast furnaces. Pramoedya was very enthusiastic about this practice. "This [steel-making] is also an urgent issue facing Indonesia. I myself once suggested to the Indonesian government that the efforts of steel-making and iron-making should be spread," Pramoedya wrote three days after arriving in Peking. "Therefore I told my Chinese host, on a short notice, that I would like to participate in steel-making. In the future I may extend this new experiment to Indonesia." 62 Pramoedya proved to be serious rather than just making a gesture: on the site where steel-making took place, he drew drafts and wrote detailed notes regarding specific procedures. ${ }^{63}$ His participation in this process had a broader symbolic implication. It was an indication that Pramoedya had gone beyond the stage of detachment and disillusionment; he had started the endeavor to change society not only by pen but, more significantly, by action.

During his 1958 trip an episode occurred in Pramoedya's personal life which may shed some light on his perceptions of the PRC. According to his biographer, Bahrum Rangkuti, Pramoedya had a romantic relationship with his Chinese interpreter. Bahrum Rangkuti wrote,

One [experience] that is no less important, which can clarify other aspects of Pramoedya's preference, is his close friendship with a Chinese woman who is fluent in Indonesian and a university graduate. It was this woman [Chen Xiaru, or Tjen Sja Yu] who translated his speeches and lectures while he was in China. For weeks both of them were in close contact, which turned friendship into love. But in the end, both of them recognized that their respective interests must take a back seat for the sake of the family and nation. This kind of situation resulted in extraordinary activities in their correspondence, which contain extensive treatment of literature, culture, and the meaning of life. ${ }^{64}$

Pramoedya had met Chen Xiaru during his first trip in 1956, when Chen was the Indonesian-language interpreter affiliated with the Writers' Union and consulted

\footnotetext{
61 Pramudya Ananta Toer, Hoa Kiau di Indonesia (Jakarta: Bintang Press, 1960), p. 37.

62 Pulamudiya Ananda Duer [Pramoedya Ananta Toer], "Liangan Luqian," [In front of the melting furnace] Chen Xiaru, trans. Renmin Wenxue 12 (1958): 16. According to Ge Baoquan, a member of the central leadership of the Writers' Union, Pramoedya participated twice in steel-making during his second China trip. See his "Zai Tashigan Bochong Xia de Yuyi" [The friendship that starts in Tashkent] Shijie Wenxue 1 (1959): 20.

63 Interview with Chen Xiaru, January 29, 1994.

64 Bahrum Rangkuti, Pramoedya, p. 23.
} 
extensively with Pramoedya regarding some cultural and technical aspects of the translation of an Indonesian novel. Pramoedya appears to have had a very good impression of her. After returning to Indonesia, he told a reporter that he was amazed that Chen Xiaru, who "had graduated from college only two years earlier and had never been to Indonesia," was able to translate Abdul Muis's Salah Asuhan [A Wrong Upbringing] into Chinese and have it published in China. A picture of Chen was included in one of Pramoedya's articles about Chinese writers and the Writers' Union. ${ }^{65}$

Pramoedya's close friendship with Chen Xiaru might have partly reinforced his admiration for the PRC. ${ }^{66}$ It perhaps had an impact on Pramoedya's subsequent creative writings as well. As Boen Oemarjati has pointed out, Pramoedya's work has "a very strong autobiographical strain and his books are his personal experiences molded into literature." 67 Chen Xiaru's image may be partially revived in Pramoedya's Footsteps, the third volume of his highly acclaimed quartet of novels. Although these novels are primarily based on the experiences of the Indonesian nationalist Tirto Adhi Suryo (who is the fictional Minke, the novels' central character), there is a certain degree of identification and confluence between the views of Minke and those of Pramoedya himself. ${ }^{68}$ A substantial portion of Footsteps is devoted to a sensitive depiction of a romantic relationship between Minke and Ang San Mei, a revolutionary youth from China after her graduation from a college, who was fluent in English and French. Minke's passionate admiration for Ang San Mei led him to propose to her. It was, however, a tragic and short-lived marriage: Ang San Mei died of disease approximately three years after they were married.

\section{The Transformation of Pramoedya: 1956-1959}

Pramoedya went through a critical transformation in his cultural outlook and political affiliation immediately after his return from China in November 1956. In

\footnotetext{
65 Hsin Pao, November 17, 1956; and Pramoedya, "Sedikit tentang Pengarang Tiongkok."

66 In his letter to an anti-communist newspaper, Jusuf Abdullah Puaar alleged that Pramoedya "is crazy about going back to China." Abadi, January 6, 1960. Chen Xiaru recalled that she received a letter from Pramoedya in 1960, informing her that he would stop in Peking for a couple of days on his way back to Indonesia from a visit to East Europe. They did not meet this time, because Chen Xiaru was assigned to work in a farm in the outskirts of Peking when Pramoedya arrived. And she later learned information from an internal report of the Writers' Union concerning Pramoedya's short stay (Interview, September 20, 1994). In a 1991 interview with a Dutch scholar, Pramoedya revealed that during his third visit he was denied the opportunity to see his Chinese friends, because his Chinese hosts insisted that "national discipline is more important than friendship." See for details in "Vraaggesprek met Pramoedya" [Interview with Pramoedya], in August Hans den Boef \& Kees Snoek, Pramoedya Ananta Toer. Essay en Interview (Breda: De Geus, 1992), p. 46. (I am thankful to Dr. Go Gien Tjwan for calling my attention to this document and Dr. William Frederick for helping me with the Dutch text.)

67 Oemarjati, "The Development," p. 323. In his written speech for the acceptance of the Ramon Magsaysay Award (September 4, 1995), entitled "Literature, Censorship and the State: How Dangerous are Stories?" Pramoedya proclaims that "each work of literature is the autobiography of its author, at a certain level and in a specific situation." Cited from Southeast Asia Discussion List <SEASIA-L@MSU.EDU>, September 6, 1995; Forwarded by Alex G. Bardsley, who has kindly informed me that this speech has been published in Suara Independen, 04, I (September 1995): 18-20.

68 See for example, Patricia Henry, "The Writer's Responsibility," pp. 63-70.
} 
reformulating his political and cultural vision for Indonesia, he constantly drew upon the inspirations he acquired from China and his understanding of PRC cultural doctrines. After the end of 1956, Pramoedya changed from a detached writer to an active fighter; his universal humanism was replaced by devout socialist realism.

\section{From Detachment to Involvement}

The first major transition of Pramoedya was political; he was transformed from a detached intellectual into a political activist. Before the end of 1956, Pramoedya was disappointed at the results of Indonesia's postcolonial development. The feeling of frustration was a main reason for Pramoedya's aloofness from society. He not only disassociated himself from any political organizations, but also ruled out ideological and political means for solving Indonesia's problems. The best way of achieving a just society, Pramoedya believed, was through cultural or social accommodation rather than through reforms in political institutions. ${ }^{69}$ The end of 1956 saw a profound shift in Pramoedya's political outlook. He was no longer preoccupied with the cultural approach to socio-political change. Instead, he came to the conclusion that political restructuring was essential not only for solving political problems, but also for coping with the cultural quandary, which had been manifested in the 1953-55 "crisis in literature" debates.

The new Pramoedya had an unambiguous political stance. In February 1957, three days after Sukarno formally announced his "Conception" for Indonesia's Guided Democracy plan, Pramoedya wrote his first political essay entitled "Djembatan Gantung dan Konsepsi Presiden" [The Suspension Bridge and the President's Conception]. It appeared in the Bintang Merah (Red Star) and the Harian Rakjat (People's Daily), ${ }^{70}$ both official publications of the PKI. The significance of this essay lay not only in its timing and the forum of publication, but in its manifestation of the author's political allegiance. In addition to pledging his firm support for Sukarno's concept of political restructuring, Pramoedya unveiled his new understanding of the PKI and its role in Indonesian history. Pramoedya admitted that in the past he had misunderstood the PKI. His anti-communist attitude, he wrote, had been formulated through reading economic and socio-political accounts by Westerners. Since Indonesian independence, Pramoedya maintained, many political parties had betrayed the people and the ideals of the revolution. The only exception was the Communist Party, which not only held steadfastly to the revolution and distanced itself from rampant corruption, but served as the sole and true representative of the people's interests. Here Pramoedya fundamentally redefined the meaning of the people. They were no longer faceless, undifferentiated, and passive "little guys." Instead, they were "workers and peasants who have provided us with food, clothing, and housing. Over the past centuries, it has also been workers who built roads and created national wealth. However, since the transfer of sovereignty, they have been abandoned ... even slandered, betrayed,

69 See details in Savitri Scherer, "From Culture to Politics: The Development of Class Consciousness in Pramoedya Ananta Toer's Writings," in Writers and Society, ed. Wang Gungwu (Canberra: Australian National University Press, 1981), pp. 239-61.

70 Pramoedya Ananta Toer, "Djembatan Gantung dan Konsepsi Presiden," Harian Rakjat, February 28, 1957; also in Bintang Merah 13, 1/2 (February 1957): 69-75. On Indonesian political change between 1957 and 1959, see Daniel Lev, The Transition to Guided Democracy: Indonesian Politics 1957-1959 (Ithaca: Cornell University Modern Indonesia Project, 1966). 
136 Hong Liu

exploited, and trampled upon."71 This newfound meaning of the people and their political representative, the PKI, was to become a "suspension bridge" for Pramoedya to enter the volatile political scene of the late 1950s and early 1960s. Pramoedya ceased to be a disengaged intellectual who only attempted to use his pen to mirror social realities. Instead, he started to be directly involved in the political change process as a devoted cultural radical.

The February 1957 essay represented a point of no return in Pramoedya's career as a cultural intellectual. In March 1957, Pramoedya, together with the painter Henk Ngantung and film director Kotot Sukardi, led a delegation of sixty-seven artists and writers to meet Sukarno in the National Palace, where they expressed their enthusiastic support for his "Conception."72 Considering that this controversial concept of Guided Democracy was still hotly debated, and that the PKI was the first major political party backing Sukarno's new plan, Pramoedya's stance had larger significance. It was a political statement for Pramoedya when he formally sided with the left-leaning political and cultural movement. From that time on, until his arrest in 1965, Pramoedya was to be closely associated with Lekra. In January 1959, shortly after coming back from his second China trip, Pramoedya was elected to Lekra's central leadership. He also served as editor of the Lentera, the literary forum of the daily Bintang Timur, which was the major cultural apparatus in the battles with non-Lekra intellectuals between 1963 and 1965.

In the transition from a detached writer to a devout fighter, Pramoedya was deeply influenced by what he observed in China. His admiration for and identification with the PRC significantly facilitated his shift to the Left. It was not a coincidence that Pramoedya formulated his new vision for Indonesia at the same time when he wrote extensively about Chinese cultural practice and the respected role of Chinese intellectuals. Pramoedya employed the Chinese expression "writers are the engineers of human souls" as a metaphor to demonstrate the need for intellectuals to be responsible to society and the nation. In a 1958 speech to school teachers in Padang, Pramoedya stated that "artists are architects and engineers of the nation who occupy an important place in society and in shaping national spirit."73 He then gave the example of Lu Xun as the model of this type of involved and dedicated intellectual. In this speech Pramoedya also attacked Western individualism and called for the support of Guided Democracy. In his January 1959 report to Lekra about the Tashkent AsianAfrican Writers Conference, Pramoedya reiterated some of the central themes he first expounded two years earlier. He admitted that in the past he had considered literature as only an expression of personal thinking, without realizing that the individual was a social entity. After acknowledging Lekra's help in shaping his views of the people, Pramoedya went on to declare that writers had an important duty in changing society. ${ }^{74}$

\footnotetext{
71 Pramoedya, "Djembatan Gantung," in Bintang Merah, p. 72.

72 Harian Rakjat, March 9, 1957.

73 Pramoedya, "Seniman adalah Insinjur Pembentuk Djiwa Bangsa," Pikiran Rakjat, June 19, 1958.

74 Pramoedya, "Lekra telah Mendidik Saja Mentjintai Rakjat," Zaman Baru (January 30-February 10, 1959): 7-10.
} 
As a consequence of the transformation in his political and cultural outlook after 1956, Pramoedya became more and more concerned with socio-political rather than cultural issues. In 1955 he planned to spend the next ten years writing a creative work and had started library research for it. ${ }^{75}$ Nevertheless, after coming back from China until 1965, Pramoedya wrote primarily political and social commentaries instead of creative works. The publication of Hoa Kiau di Indonesia (The Overseas Chinese in Indonesia) in 1960 presents a case in point. This two-hundred-page meticulously documented book was written in late 1959, at the height of the anti-Chinese movement in Indonesia. It was composed of nine lengthy letters addressed to Chen Xiaru, which first appeared in the weekly Bintang Mingguan. In this book (which was dedicated to Chen Xiaru), Pramoedya came to the defense of the Hoakiau (or Huagiao, the overseas Chinese), who were loosely referred to as those ethnic Chinese living in Indonesia. Pramoedya argued forcefully that those Indonesians who initiated the anti-Chinese movement were motivated by their own political agendas and supported by the imperialists. By quoting extensively from Dutch, Indonesian, and English materials, he demonstrated that the Indonesian Chinese should not be viewed as foreigners, because they had long been integrated with the Indonesian people. Pramoedya further contended that the Hoakiau had made significant contributions to Indonesia's economic, social, and cultural development; they should be taken as "comrades-inarms" of the Indonesian people. This book's adapted Chinese translation appeared in Indonesia, China, and other Southeast Asian countries, and the PRC government praised Pramoedya's courage in seeking justice for the overseas Chinese. ${ }^{76}$ Pramoedya himself, however, paid a high price for writing and publishing this book, which was banned soon after it was published, and he was detained by the Indonesian military authorities for nine months.

\section{From Universal Humanism to Socialist Realism}

Prior to the end of 1956, Pramoedya's cultural thought had been basically within the framework of universal humanism. He had displayed a genuine concern for the disadvantaged members of Indonesian society, and "the people" in Pramoedya's creative writings were undifferentiated. Like many other members of the intellectual elite of the time, he did not see Indonesian society as being divided by class. He also accepted the basic elite cultural tenet that the priyayi (elite), no matter how imperfect they could be, were "superior" to the wong-cilik (little guys). According to this view, "it is the priyayi who are depicted to be ones with idealism and dedication, while the wong-cilik (when they are not depicted as 'docile') are the ones who are capable of committing atrocious acts." 77

The new Pramoedya displayed a different opinion regarding the people and how they ought to be portrayed in literature. As demonstrated earlier, one of the major impressions he acquired from China was the vital importance of the people in

\footnotetext{
75 Savitri Scherer, "From Culture to Politics," p. 23.

76 See for example, Tay Kong Sian Po (Surabaya), January 4-15, 1960, Yinhua Jingji (Jakarta), January 7, 1960, Xin Yanguang Bao (Rangoon), May 3, 1960, Mianghua Ribao (Phnom Penh), April 26, 1960, and Dongnanya Yanjiu Ziliao (Canton) 1 \& 2 (1960): 2-10, 87-95. For the official Chinese comments on this book, see Renmin Ribao (People's Daily), June 23, 1960, and Jinri Xinwen, June 28, 1960.

77 Savitri Scherer, "From Culture to Politics," p. vii.
} 
revolution and nation building. The PRC cultural doctrine of "art should serve the people" reinforced Pramoedya's conviction that the people were not idle objects of oppression. He started paying greater attention to the theme of class differentiation within society and its cultural ramifications. This shift of focus began while he was still in the PRC. In the end of his first visit to China, Pramoedya gave a talk about Indonesian literature in Canton [Guangzhou]. A few new themes appeared to have surfaced in this speech. ${ }^{78}$ For example, Pramoedya thought it unfortunate that before World War II no intellectuals had been able to represent the spirit and consciousness of the peasant and working classes. He interpreted Armijn Pane's Belenggu (Shackles, 1940) and Takdir Alisjahbana's Layar Terkembang (With Sails Unfurled, 1936) as reflecting "the spiritual life of bourgeois and petit- bourgeois." Criticizing Indonesian intellectuals for their lack of connections with the people, Pramoedya declared that "in our time, there is a greater urgency in having writers like Lu Xun, a writer and thinker with a firm conviction." Pramoedya's evaluation of Indonesia's postindependence cultural development demonstrated his changing attitude toward the cultural leftists who championed the doctrine of "art serving the people." "With the founding of the People's Institute of Culture [Lekra]," Pramoedya declared, "it has become the dynamic in pushing forward the cultural development; the socialist stream has gradually gained ground among writers." He also indicated that he agreed with a notion advocated by Lekra, namely, literature was first and foremost created by life and time. ${ }^{79}$

After the end of 1956, Pramoedya developed a new appreciation of the mass-elite relationship and how this relationship should be portrayed in literature. His translation of The White-haired Girl, a Stalin Prize-winning Chinese play depicting rural class conflicts, signaled the emergence of a newfound class consciousness. ${ }^{80}$ This change was evident in the first of Pramoedya's novels written after coming back from China, Sekali Peristiwa di Banten Selatan (An Event in Southern Banten). Acknowledging the importance of "living with peasants and workers" in order to accurately interpret their life, Pramoedya "went down" to the countryside of the Banten area, where he met peasants and miners at the end of 1957. The novel had a strong political coloring, depicting class confrontation between the oppressed and the exploiters. An underlying implication was that the little guys were not merely objects of exploitation; if they united and fought against injustice their fate could be changed for the better. Although this novel was criticized as "shoddily written," 81 its political ramification overshadowed its literary imaginativeness. Shortly after the novel's publication in 1959, it was adapted for the stage by Dhalia (a Lekra-associated writer) with the title of

\footnotetext{
78 Pu A Duer [Pramoedya Ananta Toer], "Tantan Yindunixiya de Wenxue," [A talk on Indonesian literature], Wenyi Yuebao 11 (November 1958): 20-22.

79 lbid., p. 22.

80 He Tjing-tje and Ting Yi, Dewi Uban: Opera Lima Babak, Pramoedya Ananta Toer, trans. (Peking: Pustaka Bahasa Asing, 1958). It was reported that this play was showed at Medan by Lekra's local branch. Interview with Shannu (who lived in Medan in the late 1950s), July 8, 1994, Peking.

81 Savitri Scherer, "From Culture to Politics," p. 84.
} 
Orang $^{2}$ Baru dari Banten (New People from Banten) and was published by Lekra in the same year. ${ }^{82}$

By joining the left-wing cultural movement, Pramoedya became a leading prototype of the Indonesian intellectual who tried to generate cultural and political change through direct participation in this process. By the end of 1959, Pramoedya had reached a radical break from his previous belief in universal humanism and his detached attitude toward politics. He came to subscribe unambiguously to the central notion that literature and art should be effectively used for the betterment of the life of the people. In reformulating his visions for Indonesia, Pramoedya was profoundly inspired by his observations and understanding of PRC cultural doctrines and practices. China constituted a metaphor, not only mirroring his own disappointment at the undesirable results of Indonesia's postcolonial transformation, but serving as a viable model for what could be done. Put in a broader context, this new Pramoedya was a product of the complex political change of the time. President Sukarno's efforts at fundamentally restructuring Indonesian political system, also partly influenced by his own favorable views of the PRC example, ${ }^{83}$ provided Pramoedya with a new domestic political framework within which his fresh insight for Indonesia could be articulated. It was perhaps not a coincidence that Pramoedya was among the first formerly centrist intellectuals to pledge firm support for Sukarno's concept of Guided Democracy.

\section{Concluding Remarks: "The Periphery as the Center"84}

Pramoedya's new social and political consciousness was soon to be tested in a time of heightened confrontation in the cultural arena. Partly as a result of the intensified and divisive political struggle during the early 1960s, the debates on culture were increasingly politicized and polarized. Pramoedya himself was keenly aware of this situation. As he put it in 1962,

The birth of Lekra sounded the deathknoll [sic] for the 1945 Generation, already in a state of serious disorder after having been infected by Dutch cultural infiltrations. . . During the first years of its existence, the Lekra was involved in a difficult struggle to evolve the correct forms for its easthetic [sic] expression to be welded with political or ideological consciousness . . . at the present stage of Indonesian literature, there are two contrary forces: on the one hand, progressive writers inside and outside the Lekra, and on the other hand, the neutral or even

\footnotetext{
82 The play was reportedly very popular among Javanese peasants. See Liang Liji, “Pulamudiya Ananda Duer jiqi Chuangzuo," [Pramoedya Ananta Toer and his creative writings], in Dongfang Yanjiu Lunwenji [Papers on oriental studies], (Peking: Beijing Daxue Chubanshe, 1983), pp. 218-19.

${ }^{83}$ For a detailed discussion of China's influence on the conception of "Guided Democracy" and on Sukarno's views of social engineering, see Liu, "The China Metaphor," Chapter 8.

84 This phrase is borrowed from Tu Wei-ming, "Cultural China: The Periphery as the Center," in idem, ed., The Living Tree: The Changing Meaning of Being Chinese Today (Stanford: Stanford University Press, 1994), pp. 1-34.
} 
140 Hong Liu

reactionary writers who voice to [sic] the wishes of the Indonesian bourgeoisie now in the state of decay. ${ }^{85}$

Politically, Lekra writers were closely associated with the PKI and, to a lesser degree, with Sukarno, while many of the 1945 Generation writers gradually aligned themselves with the right-wing army leadership and conservative Muslims. Culturally, the two groups held opposing aesthetic views. Lekra writers firmly believed that art should serve the people and politics, while the majority of the 1945 Generation insisted that art should have its own aesthetic criteria and should be separated from politics. It was the clash of these political and cultural views that finally led to the Manikebu Affair of 1963-64. ${ }^{86}$

The incorporation of the PRC literary doctrines and practices by writers reinforced the tendency toward cultural radicalism and polarization. During the first half of the $1960 \mathrm{~s}$, this integration was facilitated by two major factors. In the first place, an increasingly left-leaning trend in Indonesia's domestic and foreign policy provided a conducive environment within which the China example was admirably perceived. The existence of a somewhat imaginary "Peking-Jakarta Axis" further contributed to the favorable receptions of the PRC in Indonesia. (In 1964 Pramoedya called for the strengthening of "the Jakarta-Peking Friendship Line," a strategic alliance that included "Cambodia, Democratic Korea, Vietnam, and the patriots in the Malay Peninsula." ${ }^{\text {87) }}$ The closing years of the Sukarno regime saw a remarkable increase in the PRC's influence on Indonesia's domestic politics. For instance, the official Indonesian news agency (Antara) used the dispatches of the New China News Agency (NCNA) not only for information regarding China, but also for its coverage of Indonesia's domestic events. ${ }^{88}$ Increasingly alarmed by the growing political influence of the Indonesian military and impressed by China's method of political indoctrination, Sukarno asked Marshal Chen Yi, China's Minister of Foreign Affairs, to come to lecture Indonesian generals in August 1965. One of the sessions lasted five hours, during which Chen Yi also spoke extensively about China's view of the world and his own analysis of international situation. ${ }^{89}$ Secondly, the first half of the 1960 s

85 Pramudya Ananta Tur, "Introducing Indonesian Literature," part 3, Harian Rakjat, September 5, 1962. Pramoedya's classification of Indonesian writers was essentially in tune with the views of Joebaar Ajoeb. See Yubaer Ayupu IJoebaar Ajoeb], "Yinni Wenxue zhong de Xin Yinshu" [New elements in Indonesian literature], Chen Xiaru, trans. Shijie Wenxue 1 (1962): 230-32. This essay was written specifically for that Chinese journal after Joebaar Ajoeb's May 1961 visit to the PRC.

86 In September 1963, sixteen intellectuals, including H. B. Jassin, Wiratmo Sukito, and Goenawan Mohamad, issued a "Cultural Manifesto" [Manifesto Kebudayaan]. In addition to reaffirming the values of "universal humanism," the Manifesto rejected the idea promoted by Lekra that artistic quality was better judged by social criteria than by self-referencing aesthetic notions. After extensive debates and fierce attacks by Lekra writers, the Manifesto was banned by Sukarno on May 8, 1964. Many of the Manifesto writers were subsequently removed from their jobs. See details in Keith Foulcher, "A Survey of Events Surrounding 'Manikebu': The Struggle for Cultural and Intellectual Freedom in Indonesian Literature," Bijdragen tot de Taal -Land - en Volkenkunde 125, 4 (1969): 429-65, and Goenawan Mohamad, "The 'Manikebu Affair': Literature and Politics in the 1960s," Prisma 46 (1988): 70-88.

87 Pu Ananda Duer, "Jiaqiang," Zhong Cheng Bao, October 1, 1964.

88 Arnold C. Brackman, The Communist Collapse in Indonesia (New York: W. W. Norton, 1969), pp. 146-47.

89 Interviews with Soeto Mei Sen, Sukarno's personal assistant and Chinese-language interpreter (May 10, 1994, Hong Kong), and with Huang Shuhai, Chen Yi's Indonesian-language interpreter (June 22, 1994, Peking). Concerning Sino-Indonesia relations during the first half of the 1960s and the interplay between 
saw the continuing attraction of the PRC to Indonesian intellectuals, especially those with a leftist persuasion. The majority of Lekra's central leaders, for example, made at least one trip to the PRC and produced a significant amount of literary romanticization of the new China. ${ }^{90}$ The PRC literary works were enthusiastically received by Indonesian readers. Song of Youth, a novel by Yang Mo about China's anti-Japanese and anti-KMT student movements in the 1930s, was translated by Shannu, an Indonesian-Chinese writer. It was published as Njanjian Remadja in 1961 and instantly became a best seller. The PKI central leadership designated this novel as required reading for its members. ${ }^{91}$ The PRC-made movie based on this novel was eagerly watched by a large number of Indonesian youths, especially those associated with the PKI. ${ }^{92}$

Throughout the first half of the 1960s, Lekra's cultural doctrines were imbued with a distinct China imprint. The most important was the notion of "politics is the commander" (politik adalah panglima), which was the creed dominating all of Lekra's artistic works. ${ }^{93}$ Other literary principles and working methods included turun ke bawah (TURBA, going down) and meluas dan meninggi (going wide and high). They bore a certain parallel with the views first elaborated by Mao Tse-tung in his 1940 Talk at the Yenan Forum on Literature and Art (the essence of which was translated by Njoto in 1950). The expression of "going wide and high," for example, was a variation on Mao's formulation of "raising art's standard and at the same time promoting its popularization." 94 "Going down," on the other hand, was the central thrust of socialist realism. Influenced by this approach, Pramoedya himself organized some Lekra writers to live among the common people and study them. ${ }^{95}$ The gradual

domestic politics and diplomacy, see David Mozingo, Chinese Policy toward Indonesia, 1949-1967 (Ithaca:

Cornell University Press, 1976), and Frederick P. Bunnell, "Guided Democracy Foreign Policy, 1960-1965: President Sukarno Moves from Non-alignment to Confrontation," Indonesia 2 (1966): 37-76.

90 See for example, Agam Wispi, et al., Dinasti 650 Djuta (Jakarta: Lekra, 1961); Sitor Situmorang, Zaman Baru (Jakarta: Madjalah Zaman Baru, 1961), [its Chinese version was translated by Chen Xiaru and published in 1963 in Pekingl; and H. R. Bandaharo, Dari Bumi Merah (Jakarta: Pembaruan, 1963). See also the analysis in Yahaya Ismail, Pertumbuhan, Perkembangan dan Kejatuhan Lekra di Indonesia (Kuala Lumpur: Dewan Bahasa dan Pustaka, 1972), pp. 57-59. Sitor Situmorang was the head of LKN (Lembaga Kebudajaan Nasional, a cultural organization of the Indonesian Nationalist Party), which was close to Lekra.

91 Interview with Shannu, July 8, 1994, Peking. See also Liao Jianyu [Leo Suryadinata], "Huawen Wenxue Fanyi zai Yinma" [Chinese literature in Indonesian and Malay translations], Asian Culture (Singapore), 15 (1991), 68.

92 Interview with Huang Shuhai (August 1993, Washington, DC); and personal correspondence from Chen Wenxian (June 6, 1993, Peking), who worked in the Cultural Section of the Chinese embassy in Jakarta and arranged the showing of this movie.

93 Pramoedya later recalled, "At that time, I did stand for the slogan 'Politics is the Commander,' I believed then that a revolution would lead to the emancipation of the people." Cited in Margaret Scott, "Waging War with Words," p. 27. See also "Vraaggesprek met Pramoedya," p. 47.

94 Mao Tse-tung, Talk at the Yenan Forum, pp. 16-18; Njoto, "Literatur Baru: Bagaimanakah Pendapat Mao Tse-tung tentang Literatur?" Republik 1, 4 (1950): 36-37. See also Mau Tje-tung [Mao Tse-tung], Front Nasional dalam Pekerdjaan Kebudajaan. Njoto, trans. (Jakarta: Lekra, 1959).

95 See Scherer, "From Culture to Politics," Chapter 8. This view of "TURBA" continues to influence Pramoedya's creative writings. According to Keith Foulcher, "Anak Semua Bangsa [Child of All Nations] is the fullest and most powerful statement ever to appear of the notion of turun ke bawah [turba] enunciated as a political and cultural principle by the PKI in the early 1960s. . . Minke's self-discovery, through Anak 
142 Hong Liu

incorporation of China-originated "revolutionary romanticism" into the Lekra cultural movement was another example. ${ }^{96}$

Therefore, the PRC cultural doctrines, which had been peripheral to the Indonesian intellectual tradition, moved to the center of cultural debates in 1960s Indonesia. Writers espousing "universal humanism" fiercely opposed to the inclusion of these PRC-originated doctrines into Indonesia. Goenawan Mohamad, one of the younger "Manifesto" members, wrote an essay in 1963 denouncing PRC literary concepts. The Chinese poet Feng Zhi [Feng Chih] had declared that "a [political] slogan is a powerful poem." Rejecting this interpretation, Goenawan Mohamad argued that poetry was a free statement which made it impossible to compare with "the hypocrite."97 Since the anti-Lekra movement aimed at "openly refusing the validity of the slogan, politics is the commander," 98 it hence also acquired a clear anti-China undertone.

In retrospect, Indonesia's left-leaning cultural movement, within which Pramoedya played a major role, procured some conceptual and practical inspirations from the PRC. A number of key Chinese literary doctrines were brought from marginality into the central stage of the Indonesian cultural polemic. The widespread incorporation and domestication of these cultural principles constituted one of the pivotal driving forces behind the accelerated trend of cultural radicalism between 1963 and 1965 . The China metaphor was thus taken beyond the realm of intellectual imagination, political symbolization, and cultural reconstruction; it became a discernible factor affecting the course of Indonesian history during the crucial closing years of the Guided Democracy era.

Semua Bangsa, rests decisively on the exercise of this principle." See Foulcher, "Bumi Manusia and Anak Semua Bangsa: Pramoedya Ananta Toer Enters the 1980s," Indonesia 32 (1981): 14-15.

96 See for details, Keith Foulcher, Social Commitment in Literature and the Arts: The Indonesian "Institute of People's Culture" 1950-1965 (Clayton, Victoria: Centre of Southeast Asian Studies, Monash University, 1986), pp. 107-111.

97 Mohamad, "Seribu Slogan dan Sebuah Puppisi" (1963), in idem, Potret Seorang Penjair Muda Sebagai Si Malin Kundang (Jakarta: Pustaka Jaya, 1972), pp. 31-32.

98 Mohamad, "The Manikebu Affair,", p. 82. 


\section{Appendix - List of Chinese Characters}

$\begin{array}{ll}\text { Ba Ren (Wang Renshu) } & \text { 巴人 (王任叔) } \\ \text { Chu Tunan } & \text { 楚图南 } \\ \text { Ding Ling [Ting Ling] } & \text { 丁玲 } \\ \text { Feng Zhi [Feng Chih] } & \text { 冯至 } \\ \text { Guo Moruo [Kuo Mo-jo] } & \text { 郭沫若 } \\ \text { Guo Xiaochuan } & \text { 郭小川 } \\ \text { Hsin Pao (Jakarta) } & \text { 《新报》 } \\ \text { Huaqiao [Hoakiau] } & \text { 华侨 } \\ \text { Huang Zhen } & \text { 黄镇 } \\ \text { Jinri Xinwen (Peking) } & \text { 《今日新闻》 } \\ \text { Li Rui } & \text { 李锐 } \\ \text { Liu Baiyu } & \text { 刘白羽 } \\ \text { Liu Zhixia [Liu Tje Sie] } & \text { 刘之侠 } \\ \text { Lu Xun [Lu Hsun] } & \text { 鲁迅 } \\ \text { Mao Dun [Mao Tun] } & \text { 茅盾 } \\ \text { Pramoedya Ánanta Toer } & \text { 普拉穆迪亚・阿南达・杜尔 } \\ \text { Renmin Ribao (Peking) } & \text { 《人民日报》 } \\ \text { Renmin Wenxue (Peking) } & \text { 《人民文学》 } \\ \text { Shijie Wenxue (Peking) } & \text { 《世界文学》 } \\ \text { Song of Youth (Njanjian Remadja) } & \text { 《青春之歌》 } \\ \text { Tay Kong Sian Po (Surabaya) } & \text { 《大公商报》 } \\ \text { Wenyi Bao (Peking) } & \text { 《文艺报》 } \\ \text { Wenyi Yuebao (Shanghai) } & \text { 《文艺月报》 } \\ \text { White-Haired Girl (Dewi Uban) } & \text { 《白毛女》 } \\ \text { Yang Mo } & \text { 杨沫 } \\ \text { Yang Shuo } & \text { 杨朔 } \\ \text { Yinhua Jingji (Jakarta) } & \text { 《印华经济》 } \\ \text { Zhong Cheng Bao (Jakarta) } & \text { 《忠诚报》 } \\ \text { Zhou Yang [Tjau Jang] } & \text { 周扬 } \\ & \end{array}$


